\title{
Investigating The Relationship Between Critical Thinking Skills and Mathematical Problem Solving Achievements of Secondary Education Students
}

\author{
Lütfi Üredi \\ Mersin University, Turkey \\ Pelin Kösece \\ Çukurova University, Turkey
}

Doi:10.19044/ejes.v7no2a11 URL:http://dx.doi.org/10.19044/ejes.v7no2a11

\begin{abstract}
In this research, it was aimed to determine the relationship between critical thinking skills and mathematical problem solving achievements of the secondary education students. Descriptive screening model was determined as the method of the research. The study group of the research included totally 429 students chosen randomly among the secondary education students studying at the $5^{\text {th }}, 6^{\text {th }}$ and $7^{\text {th }}$ grades of state schools affiliated to Adana province Seyhan district National Education Directorate in 2018-2019 academic year. As data collection tools, "Critical Thinking Scale" developed by Görücü (2014) in accordance with the level of secondary education, and "Problem Solving Success Determination Test" developed by Kösece Loğoğlu (2016) were used. Data were analyzed in SPSS 22.0 statistical software. As a result of the analyses, it was determined that there was a positive significant relationship between "looking for the truth" and "communication" subdimensions of problem solving achievements and critical thing skills scale. In accordance with the results obtained from the study, considering the suggestions below was remarkable in terms of improving critical thinking skills and mathematical problem solving success of the secondary education students: The lessons should be lectured with activities related to getting the students acquire a critical point of view for solving the mathematical problems. The studies of establishing problems should also be carried out besides the studies of solving mathematical problems for the students. The teachers should primarily be individuals who can think critically for getting students acquire critical thinking skills, and necessary training should be provided for providing teachers to acquire this skill.
\end{abstract}

Keywords: Looking for the truth, analyzing, point of view, questioning. 


\section{Introduction}

Societies have gradually added new information to the current one, and improved in the light of technological developments. Because our age is called information society, acquiring, analyzing knowledge and using it as required have become our fundamental vital skills. Our surrounding is full of information on ay areas, and our part is to analyze this information well. Because understanding the information accurately and using it in the right place is a fairly difficult skill. For this very reason, individuals who grasp the information from different viewpoints, approach critically and benefit from these skills efficiently while overcoming the problems have become critical for the societies.

According to Seferoğlu and Akbiyık (2006), requirements of modern world have required individuals to have thinking skills. In education, individuals who think, criticize, produce and know how to reach information have been tried to be raised. "The most important task schools have recently been expected to fulfill is to raise responsible citizens who can think in a democratic, creative, critical and multi-dimensional way, learn to learn, solve problems, who are respectful to others and tolerant of different ideas" (Aybek, 2006). The way for having these aforementioned skills is possible to be an individual who can question the information, look it from different viewpoints and adapt it into new situations instead of having it passively. All these skills directly indicate critical thinking. Because critical thinking enables individuals to accept information by questioning and making accurate decisions developing different viewpoints (Dutoğlu and Tuncel, 2008). The decisions taken in this sense are possible to be mentioned as providing conveniences for individuals on overcoming the problems.

According to Paul and Elder (2013), critical thinking is a way of thinking including three stages one within the other as analyzing the thought, evaluating the thought and developing the thought. Although critical thinking has different definitions, it is possible to mention that acquiring, comparing, evaluating and using the knowledge efficiently are emphasized in nearly all definitions (Aybek, 2007, P3). According to Nosich (2001), critical thinking has three parts. The first of these parts is critical thinking's including asking questions; the second is critical thinking's including trying to answering these questions through comprehending their logic; and the third part is critical thinking's including believing in outcomes of our logic (Aybek, 2015, 5-6). As could be seen here, the beginning point of all these three parts is asking a question. Namely, for starting a new process, creating questions is essential to see all dimensions of events and understand better. The subsequent is the stage of solving, and this is inter-bedded with the process of problem solving. According to Korkut (2002), problem solving is a process beyond simply employing the rules acquired at the end of experiences in order to overcome a 
problem. Problem solving process necessitates finding new ways of solution. In this sense, it is necessary to benefit from critical thinking process while creating questions related to solution and looking for answers to these. The third stage of critical thinking is to reach logical results. Coming closer to a result and making a logical inference require critical thinking. According to Alkın Şahin and Tunca (2015), fuzzy thinking appears is the words are unspecific and inferences are not presented well. Fuzzy thinking can be considered as an obstacle for individuals' overcoming a problem.

No doubt, educational systems are the ones that are affected from the changes in thinking skills, and gradually reflecting this effect to whole society via the individuals. In our country, changes in skills to be acquired by the students have appeared through the constructivist approach in education. Including different skills in curriculums has necessitated lecturing the lessons in a way enabling the students acquire these skills. Problem solving and critical thinking skills are among these. Because these two skills and all other basic skills have a complementary quality. Accordingly, development of critical logic has become compulsory, and efforts towards supporting modern individuals for thinking critically to understand realities of the world in many ways have increased (Akar, Vural \& Kutlu, 2004). Effects of these increasing efforts have become evident in researches on any areas of education.

In educational environments, problem solving as another skill that is closely associated with critical thinking and expected to be acquired by the students is frequently encountered by the individuals in both mathematical domains and life. In fact, individuals encounter with small or big problems in their daily lives even they are not aware of these. In daily works such as shopping, banking, etc., there are problems to be overcome, and problems do not disappear if the owner of the problem takes any action. The basis for such problems and the basis for mathematical four-operation problems are similar. The individuals use the same mental processes while solving a mathematical problem and a verbal problem. For that reason, the approaches acquired by the students while solving mathematics problems affect them during their whole life.

Kayan and Çakıroğlu (2008) mentioned that problem solving should be integrated in all educational grades and mathematical subjects in reform studies related to mathematic education. Because problem solving is available in any areas of life as mentioned above. Olkun and Toluk (2004, P44) defined problem as a case that encourages individuals to solve and that has no ready solving procedure but individuals can overcome using their knowledge and experiences. As could be understood from this definition, problem solving is a process that actualizes depending upon different points of view. Individuals' using their knowledge and experiences related to current problem indicates critical thinking skill. 
Problem solving that leads a mark in this age is among the purposes of all courses. It should be known that teaching method of the $21^{\text {st }}$ century is problem solving. For that reason, problem, structure of problem solving and increasing success in problem solving are the subjects that are studied by many researchers (Kılıç \& Samanc1, 2005). Mathematical problem solving processes that are both sub-dimension and basis of this subject are the ones that necessitate using a critical viewpoint, and a relationship between these two skills is considered to be present. Many studies have been carried out investigating the relationship between critical thinking and problem solving skills that includes overcoming the problems of daily life in different educational grades and professional groups (Koray et al., 2007; Cantürk, Günhan \& Başer, 2009; Beşer \& Kissal, 2009; Choi, Lindquist \& Song, 2014). A similar relationship is also considered to be present between mathematical problem solving and critical thinking skill. However, in the literature, it has been regarded that there are limited number of studies related to the presence and grade of such a relationship. For that reason, in this study, the relationship of mathematical problem solving skill with critical thinking skills was investigated in terms of various variables. This gap in the literature was tried to be filled with this research.

\section{Purpose of the Research}

In today's educational understanding, individuals who can integrate themselves into the society, think freely, looks from different perspectives, and produce creative ideas have become remarkable. Critical thinking that is the building stone for all these properties has become one of the most important skills every student should acquire. Because individuals who have critical thinking skill are the ones who can adapt into changing and developing world without experiencing difficulty in adaptation into differences. For that reason, organizing the educational environments in a way students can acquire this skill has become an obligation. The secondary education grade includes the period when students start to use different viewpoints while interpreting the events in terms of their developmental properties. Problem solving is one of these skills in different types. The basis of problem solving skill is laid in mathematical problem solving processes. Because individuals with mathematical problem solving skill can conclude problem solving process accurately approaching to the problems they encounter in real life scientifically. When the literature is analyzed, it is seen that the effects of various variables are examined in the studies the relationship between the critical thinking skills and problem solving achievements of secondary education students (Elliott, Oty, McArthur \& Clark, 2001; Thompson, Martin, Richards \& Branson, 2003; Son and Song, 2012; Peter, 2012). However, the number of studies that use mathematical problem solving skills in particular 
was noteworthy. So, it was considered that the relationship between critical thinking skill and mathematical problem solving achievement should be revealed in terms of different variables. Therefore, in this study, it was aimed to determine the relationship between critical thinking skills and mathematical problem solving achievement of the students in secondary education grade. Within this framework, answers to the questions below were sought:

1. Does critical thinking skill score averages of secondary education students differ significantly according to their level of grade?

2. Does mathematical problem solving achievement score averages of secondary education students differ significantly according to their level of grade?

3. Does critical thinking skill score averages of the female and male students with different reading habit differ significantly?

4. Does mathematical problem solving achievement skill score averages of the female and male students with different reading habit differ significantly?

5. Is there a significant relationship between critical thinking skills (i.e. communication, looking for the truth, prejudice and self-confidence) and mathematical problem solving achievements of secondary education students?

\section{Method}

The research focused on gaining a general perspective on the subject of research by understanding the nature and characteristics of the events. This study carried out for determining the relationship between critical thinking skills and mathematical problem solving achievement of secondary education students, that was aimed to reveal the case as it was. Descriptive researches define the relevant case; it has the purpose of describing a current case in screening model (Karasar, 2008). Therefore, a descriptive correlational survey model has been determined as the method of the research. In the correlational survey model, it is aimed to determined the presence of co-variation between two and more variables (Bahtiyar and Can, 2016). Also it is aimed to reach a wide sample in accordance with the chosen method.

\section{Sample}

The population of this research included secondary education students. The sample used to represent the population included totally 429 students chosen randomly at the $5^{\text {th }}, 6^{\text {th }}$ and $7^{\text {th }}$ grades in state schools affiliated the Ministry of National Education in Seyhan district of Adana province in 20182019 academic year. Stratified sampling method was used while determining the sample. Stratified sampling guarantees sub-groups in the population to be represented in the sample (Balc1, 2007). With the determined stratified 
sampling method, it was aimed to increase the representation of the universe. For this, the universe was initially divided into three layers according to the grade level, and then neutral samples from each layer were selected and united. $216(50.3 \%)$ of secondary education students who participated into the study were female and $213(49.7 \%)$ were male. The close numbers in terms of female and male students was remarkable in terms of increasing the reliability of analyses performed for gender variable. $180(42.0 \%)$ of the students who participated into the study studied at the $5^{\text {th }}$ grade, $72(16.8 \%)$ studied at the $6^{\text {th }}$ grade, and $177(41.3 \%)$ studied at the $7^{\text {th }}$ grade. $114(26.6 \%)$ of the students who participated into the study read a book every day, $231(53.8 \%)$ read twice a week, $66(15.4 \%)$ read once a week, and $18(4.2 \%)$ read at any times.

\section{Data Collection Tools}

In accordance with the research problem and sub-problems, "Critical Thinking Scale" developed by Görücü (2014) was used for measuring critical thinking skills of the $6^{\text {th }}, 7^{\text {th }}$ and $8^{\text {th }}$ grade students. This scale was a 5-point Likert type, and included 17 items. The reliability obtained from whole scale was calculated to be 0.70 by Görücü (2014). The educational grade the scale included was noticed to be appropriate for the students in the sample of the research. Reliabilities of the dimensions in "Critical Thinking Scale" were reposted by Görücü (2014) (See, Table 1).

Table 1. Dimensions of Critical Thinking Scale and Reliability of Dimensions

\begin{tabular}{|c|c|c|c|c|}
\hline Dimensions & $\begin{array}{ll}\text { Name } & \text { of } \\
\text { Dimension } & \end{array}$ & $\begin{array}{l}\text { Number of } \\
\text { Items }\end{array}$ & Items & Reliability \\
\hline $1^{\text {st }}$ Dimension & Communication & 4 & $5,6,8,17$ & .45 \\
\hline $2^{\text {nd }}$ Dimension & $\begin{array}{l}\text { Looking for the } \\
\text { truth }\end{array}$ & 6 & $\begin{array}{l}1,3,7,10 \\
13,14\end{array}$ & .58 \\
\hline $3^{\text {rd }}$ Dimension & $\begin{array}{l}\text { Self- } \\
\text { Confidence }\end{array}$ & 3 & $2,12,16$ & .66 \\
\hline $4^{\text {th }}$ Dimension & Prejudice & 4 & $4,9,11,15$ & .63 \\
\hline
\end{tabular}

"Problem Solving Achievement Determining Test" developed by Kösece Loğoğlu (2016) in order to determine the mathematical problem solving achievement of the participants was used. This test included question types every student at any grades of the secondary education grade could answer. This test consists of 20 multiple choice items. Reliability coefficient for the Problem Solving Achievement Determining Test was calculated to be 0.80 by Kösece Loğoğlu (2016). 
In addition to these two data collection tools, for determing the gender of students, level of grade and reading habits a personal information text is prepaired.

\section{Data Analysis}

SPSS 22 (Statistical Package for Social Sciences) statistical software was used to analyze the data obtained in the research. Percentage and frequency analyses were performed for determining the demographical distributions of the participants; two-factor ANOVA at $\mathrm{p}<.05$ level of significance was used for specifying the transactional effect in multiple-group comparisons; T-Test and One-Way ANOVA were used for group comparisons; and Pearson correlation coefficients were analyzed to determine the relationship between critical thinking skills and mathematic achievement.

\section{Findings}

In this section, the results of the analyses performed for the subproblems of the research were included.

The analysis results performed for the first sub-problem of the research as "Does critical thinking skill score averages of secondary education students differ significantly according to their level of grade?" were explained.

As result of the analyses, critical thinking skill score averages of the $7^{\text {th }}$ grade students was calculated to be $x=3.56$, critical thinking skill score averages of the $6^{\text {th }}$ grade students was calculated to be $x=3.76$, and critical thinking skill score averages of the $5^{\text {th }}$ grade students was calculated to be $x=3.65$. According to One-Way ANOVA test results, critical thinking skills of the $6^{\text {th }}$ grade students were determined to be higher, and this difference was significant $\mathrm{F}(2,426)=5.66, \mathrm{P}<.01$.

The analysis results performed for the second sub-problem of the research as "Does mathematical problem solving achievement score averages of secondary education students differ significantly according to their level of grade?" were explained.

As result of the analyses, mathematical problem solving achievement score averages of the $7^{\text {th }}$ grade students was calculated to be $\bar{x}=.58$, mathematical problem solving achievement score averages of the $6^{\text {th }}$ grade students was calculated to be $\bar{x}=.42$, and mathematical problem solving achievement score averages of the $5^{\text {th }}$ grade students was calculated to be $\overline{\mathrm{x}}=.37$. According to One-Way ANOVA test results, there was a significant difference between mathematical problem solving achievement of secondary education students in terms of their level of grade $\mathrm{F}(2,426)=74.56, \mathrm{P}<.01)$. Results of the Scheffe test performed to determine the source of difference in terms of level of grade were presented in Table 2. 
Table 2. Distribution Indicating Scheffe Test Comparison Related to Mathematics Problem Solving Achievement of Research Group According to the Variable of Grade

\begin{tabular}{llllll}
\hline & $\overline{\mathbf{x}}$ & $\begin{array}{l}\text { Grade } \\
\text { Variables }\end{array}$ & $\overline{\mathrm{x}}$ & $\begin{array}{l}\text { Mean } \\
\text { Difference }\end{array}$ & $\mathbf{p}$ \\
\hline $\mathbf{5}^{\text {th }}$ & .37 & $6^{\text {th }}$ Grade & .42 & -.04 & .104 \\
Grade & & $7^{\text {th }}$ Grade & .58 & $-.21^{*}$ & .0 \\
\hline $\mathbf{6}^{\text {th }}$ & .42 & $5^{\text {th }}$ Grade & .37 & .04 & .104 \\
Grade & & $7^{\text {th }}$ Grade & .58 & $-.16^{*}$ & .0 \\
\hline $\mathbf{7}^{\text {th }}$ & .58 & $5^{\text {th }}$ Grade & .37 & $.21^{*}$ & .00 \\
Grade & & $6^{\text {th }}$ Grade & .42 & $.16^{*}$ & .0 \\
\hline
\end{tabular}

According to Scheffe test results performed to determine the source of difference in terms of level of grade, $7^{\text {th }}$ grade students $(x=.58)$ were noticed to be more successful rather than the $5^{\text {th }}$ grade students $(\bar{x}=.37)$ in terms of mathematical problem solving achievement.

The analysis results performed for the third sub-problem of the research as "Does critical thinking skill score averages of the female and male students with different reading habit differ significantly?" were presented below.

Table 3 indicated the descriptive statistics related to critical thinking skills of the female and male secondary education students with different reading habits.

Table 3. Descriptive Values Related to Gender and Reading Habits of Secondary Education Students

\begin{tabular}{|c|c|c|c|c|c|c|c|c|c|c|}
\hline \multirow{2}{*}{\multicolumn{2}{|c|}{$\begin{array}{l}\text { Gender } \\
\text { Reading } \\
\text { Habit }\end{array}$}} & \multicolumn{3}{|c|}{ Female } & \multicolumn{3}{|c|}{ Male } & \multicolumn{3}{|c|}{ Total } \\
\hline & & $\mathbf{n}$ & $\overline{\mathbf{x}}$ & $\mathbf{S}$ & $\mathbf{n}$ & $\overline{\mathbf{x}}$ & $\mathbf{S}$ & $\mathbf{n}$ & $\overline{\mathbf{x}}$ & $\mathbf{S}$ \\
\hline $\begin{array}{l}\text { Every } \\
\text { day }\end{array}$ & & 72 & 3.76 & .45 & 42 & 3.79 & .41 & 114 & 3.78 & .43 \\
\hline $\begin{array}{l}\text { Twice } \\
\text { Week }\end{array}$ & $\mathbf{a}$ & 114 & 3.61 & .41 & 117 & 3.53 & .45 & 231 & 3.57 & .43 \\
\hline $\begin{array}{l}\text { Once } \\
\text { Week }\end{array}$ & $\mathbf{a}$ & 27 & 3.64 & .42 & 39 & 3.62 & .54 & 66 & 3.63 & .49 \\
\hline Never & & 3 & 3.59 & 0 & 15 & 3.49 & .52 & 18 & 3.5 & .47 \\
\hline Total & & 216 & 3.67 & .43 & 213 & 3.6 & .47 & 429 & 3.63 & .45 \\
\hline
\end{tabular}


As could be seen in Table 5, reading habit in female students was analyzed to be highest in "twice a week" $(\mathrm{n}=114)$. Reading habit of the male students was determined to be highest in "twice a week" $(\mathrm{n}=117)$. The lowest value in reading habits of female and male students was in "never" choice.

After performing analyses related to normal distribution of the data, factorial ANOVA was performed for transactional-determination of the significant difference between critical thinking skill levels of female and male students in terms of reading habit, and the results were presented in Table 4.

Table 4. Two-Way ANOVA Results Related to the Difference between Critical Thinking Skills of Female and Male Students with Different Reading Habits

\begin{tabular}{|c|c|c|c|c|c|c|}
\hline $\begin{array}{l}\text { Source of } \\
\text { Variance }\end{array}$ & $\begin{array}{l}\text { Sum of } \\
\text { Squares }\end{array}$ & Sd & $\begin{array}{l}\text { Mean } \\
\text { Squares }\end{array}$ & $\mathbf{F}$ & $\mathbf{p}$ & $\eta$ \\
\hline $\begin{array}{l}\text { Gender } \\
\text { (G) }\end{array}$ & .06 & 1 & .06 & .3 & .58 & .0 \\
\hline $\begin{array}{l}\text { Reading } \\
\text { Habit (R) }\end{array}$ & 3.29 & 3 & 1.1 & 5.57 & .00 & .03 \\
\hline $\mathbf{G} * \mathbf{R}$ & .26 & 3 & .09 & .44 & .73 & .0 \\
\hline Error & 82.8 & 421 & .2 & & & \\
\hline Total & 5740.33 & 429 & & & & \\
\hline
\end{tabular}

According to $2 \times 4$ Two-Way ANOVA test results, as could be seen in Table 6, no significant difference was determined between critical thinking skill levels of the secondary education students in terms of their gender and reading habits. Moreover, no significant difference was also determined in common effect of gender and reading habit $\mathrm{F}(3,421)=.44, \mathrm{p}>.05$. When partial eta squared variable was analyzed, it was noticed that reading habit and gender and common effect of reading habit and gender had low effect upon critical thinking skill level $(\boldsymbol{\eta}<.06)$.

When the critical thinking skill score averages of female and male students were analyzed, skill score averages of female students $(\bar{x}=3.67)$ were noticed to be slightly higher rather than skill score averages of the male students $(\overline{\mathrm{x}}=3.6)$. However, this difference was not at a significant level. Similarly, when critical thinking skill score averages of the students were analyzed according to reading habit, it was determined that skill score averages of the students who read books every day $(\bar{x}=.48)$ were noticed to be significantly higher $(\mathrm{p}<.05)$.

The analysis results performed for the fourth sub-problem of the research as "Does mathematical problem solving achievement skill score 
averages of the female and male students with different reading habit differ significantly?" were presented below.

Table 5 indicated the descriptive statistics related to mathematical problem solving achievements of the female and male secondary education students with different reading habits.

Table 5. Descriptive Values Related to Gender and Reading Habits of Secondary Education Students

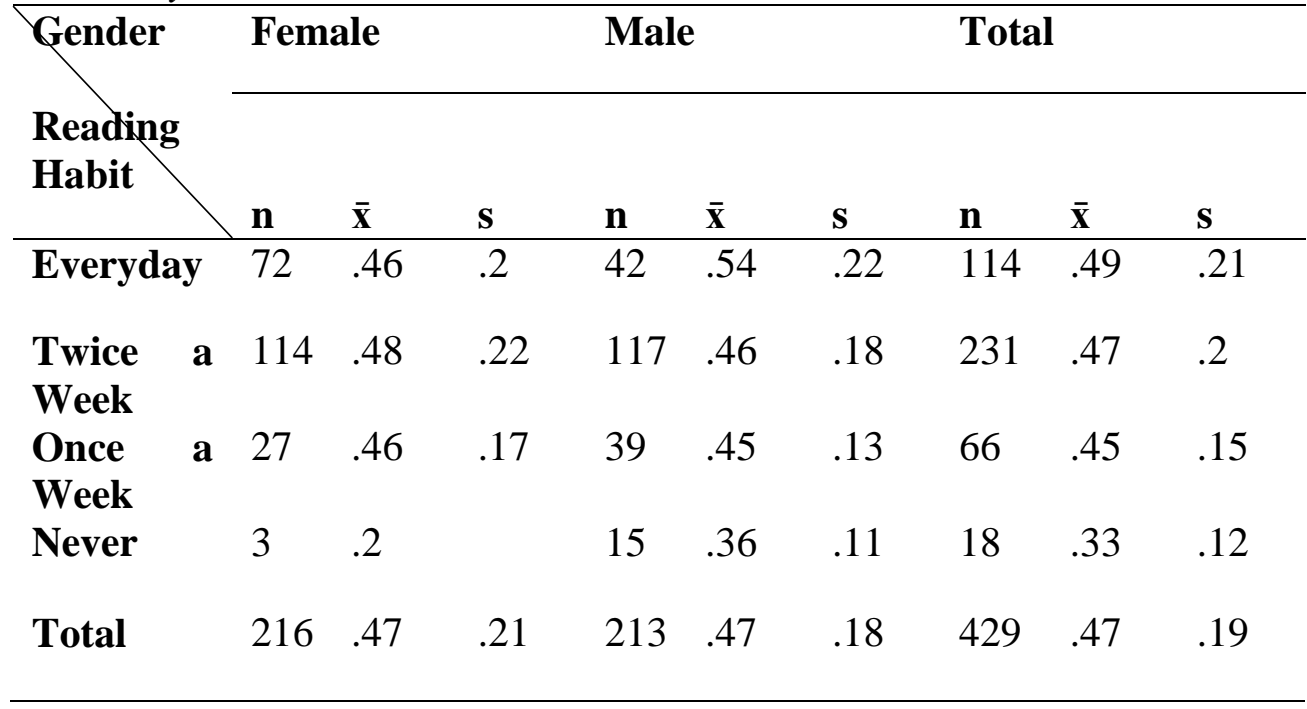

As could be seen in Table 5, reading habit was analyzed to be highest in "twice a week" choice in female students $(\mathrm{n}=114)$. In terms of male students, reading habit was noticed to be highest in "twice a week" choice $(\mathrm{n}=117)$. The choice of "never" was determined to be lowest in terms of reading habit in both female and male students.

After performing analyses related to normal distribution of the data, factorial ANOVA was performed for transactional-determination of the significant difference between mathematical problem solving achievement skill levels of female and male students in terms of reading habit, and the results were presented in Table 6 . 
Table 6. Two-Way ANOVA Results Related to the Difference between Mathematics Problem Solving Achievement of Female and Male Students with Different Reading Habits

\begin{tabular}{lllllll}
\hline $\begin{array}{l}\text { Source of } \\
\text { Variance }\end{array}$ & $\begin{array}{l}\text { Sum of } \\
\text { Squares }\end{array}$ & Sd & $\begin{array}{l}\text { Mean } \\
\text { Squares }\end{array}$ & F & p & $\boldsymbol{\eta}$ \\
\hline $\begin{array}{l}\text { Gender } \\
\text { (G) }\end{array}$ & .09 & 1 & .09 & 2.48 & .12 & .0 \\
Reading & .47 & 3 & .16 & 4.34 & .005 & .03 \\
$\begin{array}{l}\text { Habit (R) } \\
\text { G*R }\end{array}$ & .25 & 3 & .08 & 2.32 & .08 & .02 \\
Error & 15.29 & 421 & .04 & & & \\
Total & 110.13 & 429 & & & & \\
\hline
\end{tabular}

According to Two-Way ANOVA test results, as could be seen in Table 6 , no significant difference was determined between mathematical problem solving achievement skill levels of the secondary education students in terms of their gender and reading habits. Furthermore, no significant difference was also determined in common effect of gender and reading habit $\mathrm{F}(3,421)=2.32$, $\mathrm{P}>$.05.

When the mathematical problem solving achievement skill score averages of female and male students were analyzed, skill score averages of male students $(\bar{x}=.47)$ were noticed to be slightly higher rather than skill score averages of the female students $(\overline{\mathrm{x}}=.47)$. However, this difference was not at a significant level. Similarly, when mathematical problem solving achievement skill score averages of the students were analyzed according to reading habit, it was determined that skill score averages of the students who read books every day $(\overline{\mathrm{x}}=.48)$ were noticed to be significantly higher $(\mathrm{p}<.05)$.

The analysis results performed for the fourth sub-problem of the research as "Is there a significant relationship between critical thinking skills and mathematical problem solving achievements of secondary education students?" were presented in Table 7. 
Table 7. Findings Related to the Relationship between Mathematics Problem Solving Achievement and Critical Thinking Skills Scale Sub-Factors

\begin{tabular}{|c|c|c|c|c|c|}
\hline & $\begin{array}{l}\text { Looking } \\
\text { for the } \\
\text { Truth }\end{array}$ & Communication & $\begin{array}{l}\text { Self- } \\
\text { Confidence }\end{array}$ & Prejudice & $\begin{array}{l}\text { Mathematical } \\
\text { problem } \\
\text { solving } \\
\text { achievement }\end{array}$ \\
\hline $\begin{array}{l}\text { Looking for the } \\
\text { Truth }\end{array}$ & $\mathrm{r}=.1$ & & & & \\
\hline Communication & $\mathrm{r}=.64^{*}$ & $\mathrm{r}=1$ & & & \\
\hline Self-Confidence & $r=-.04$ & $\mathrm{r}=.08$ & $\mathrm{r}=1$ & & \\
\hline Prejudice & $\mathrm{r}=-.18^{*}$ & $\mathrm{r}=-.03$ & $\mathrm{r}=.30 *$ & $\mathrm{r}=1$ & \\
\hline $\begin{array}{l}\text { Mathematical } \\
\text { problem solving } \\
\text { achievement }\end{array}$ & $\mathrm{r}=.22 *$ & $\mathrm{r}=.2^{*}$ & $\mathrm{r}=-.28^{*}$ & $\mathrm{r}=-.25^{*}$ & $\mathrm{r}=1$ \\
\hline
\end{tabular}

When the statistical data in Table 7 were analyzed, it was noticed that there was a positive significant relationship between "looking for the truth" $(\mathrm{r}=.22, \mathrm{p}<.05)$ and "communication" $(\mathrm{r}=.2, \mathrm{p}<.05)$ sub-dimensions of critical thinking skills scale; and there was a negative significant relationship between "self-confidence" $(\mathrm{r}=-.28, \mathrm{p}<.05)$ and "prejudice" $(\mathrm{r}=-.25, \mathrm{p}<.05)$ subdimensions.

\section{Discussion, Conclusion and Recommendations}

In this research, it was aimed to analyze the relationship between critical thinking skills and mathematical problem solving achievements of secondary education students, and to interpret these after analyzing in terms of various variables.

In accordance with obtained findings, critical thinking skills core averages of the $6^{\text {th }}$ grade students were found to be significantly higher between the critical thinking skills and level of grade of the secondary education students. This could be arisen from the subjects in sixth grade students' curriculum's requiring to discuss the problems on real life basis while solving problems. In the study carried out by Akar (2007), it was reported that age had no determining effect upon critical thinking skill. This could be arisen from study group's including participants with closer grade levels and ages, accordingly. However, in this research, closer age groups necessitated analyzing the dimension of age in depth. 
Another result obtained from the research was that mathematical problem solving achievement of secondary education students differed significantly in terms of "level of grade" variable. As result of the analyses, it was concluded that this difference was arisen from the fact that mathematical problem solving achievement scores of the $7^{\text {th }}$ grade students were higher rather than the scores of $5^{\text {th }}$ grade students. This was considered to be resulted from the structure of mathematic course. Mathematics has a spiral structure. The subjects in mathematics have a recurrent quality. For example, fouroperation skill acquired in elementary education grade is encountered in secondary education, high school, university and even in any areas of life. For that reason, acquisition and using level of this skill increases as the age gets older. Because the skill of four-operation is correlational with mathematical problem solving achievement skill, obtaining such a result is expectable.

Furthermore, no significant difference was obtained between critical thinking skills and mathematical problem solving achievements of female and male students with different reading habits. Whereas the findings related to insignificant difference according to gender in terms of problem solving skills were parallel with the findings in the literature (Güven \& Akyüz, 2001; Özkütük et al., 2003), these findings were inconsistent with the ones in the researches carried out by Koray and Azar (2008) and Korkut (2002). This difference could be arisen from the difference in study sample. Another result obtained from relevant sub-problem of the research was that gender created no difference in critical thinking skills. This finding was associated with the ones in the studies in the literature (Özdemir, 2005; Şen, 2009). On the other hand, these findings were inconsistent with the ones in the researches carried out by Walsh and Hardy (1999) and Neilsen (1984). Different reading habits had a significant effect upon critical thinking and mathematical problem solving achievement skill in favor of students who read books every day. Upon this result, students' reading qualified books, their reading books comprehendingly, or having extra reading hours to course hours were possible to be efficient. According to Tanju (2010), reading skill enabled all developmental areas including cognitive and oral development to improve. For that reason, it was possible to mention that students who acquired reading habit were more advantageous on thinking, problem solving and capability development.

In the research, there was a positive significant relationship between "looking for the truth" and "communication" sub-dimensions of critical thinking skills scale and mathematical problem solving achievement of secondary education students. And there was a negative significant relationship between "self-confidence" and "prejudice" sub-dimensions of critical thinking skills scale and mathematical problem solving achievement of secondary education students. When the literature was reviewed, it was 
remarkable that there were limited number of studies investigating the relationship between critical thinking skills and mathematical problem solving achievement. The studies were mostly carried out on critical thinking and problem solving skill. Whereas no significant relationship was found between problem solving and critical thinking skills in the study carried out by Gürleyük (2008), a significant relationship was determined between critical thinking and problem solving in the study carried out by Tümkaya et al. (2009). In the literature, it was reported that critical thinking skill provided a basis for problem solving skill (Dil, 2001; Özdemir, 2005; Akar, 2007; Can et al., 2009). The result related to the relationship between some dimensions of critical thinking scale and mathematical problem solving achievement was consistent with the results in the literature.

In accordance with the results obtained from the study, regarding the suggestions below related to improving the critical thinking skills and mathematical problem solving achievements of secondary education students is remarkable:

1. The courses should be lectured with activities related to making students acquire a critical viewpoint while solving mathematics problems.

2. Students should be provided to create mathematic problems with real life context besides the mathematical problem solving studies. So that students can develop their skills establishing relationships between mathematic problems and real life problems.

3. Teachers should primarily be individuals who can think critically; therefore, in-service training activities should be organized for teachers to acquire critical thinking skills.

\section{References:}

1. Akar Vural, R., \& Kutlu, O. (2004). Critical thinking: examination of measurement tools and a reliability study. Cukurova Üniversitesi Sosyal Bilimler Enstitüsü Dergisi, 13(2), 189-200.

2. Akar, C. (2007). Critical thinking skills of elementary school students. Doctoral Dissertation. Gazi Üniversitesi Eğitim Bilimleri Enstitüsü, Ankara.

3. Akar, Ü. (2007). The relationship between student teachers' scientific process skills and critical thinking. Master Thesis. Afyon Kocatepe Üniversitesi Sosyal Bilimler Enstitüsü, Afyon.

4. Alkın-Şahin, S., \& Tunca, N. (2015). Philosophy and critical thinking. Trakya Üniversitesi Ĕ̈itim Fakültesi Dergisi, 5(2), 192-206.

5. Aybek, B. (2006). The effect of content and skill based critical thinking teaching on prospective teachers'disposition and level in critical 
thinking. Doctoral Dissertation. Çukurova Üniversitesi Sosyal Bilimler Enstitüsü, Adana.

6. Aybek, B. (2007). The role of the teacher in teaching critical thinking. Bilim, Eğitim ve Düşünce Dergisi, 7(2).

7. Bahtiyar, A., \& Can, B. (2016). An Investigation of Problem-Solving Skills of Preservice Science Teachers. Educational Research and Reviews, 11(23), 2108-2115.

8. Balc1, A. (2007). Research in social sciences: Methods, techniques and principles. Ankara: Pegem A Yayıncilık.

9. Beşer, A., \& KISSAL, A. (2009). Critical thinking dispositions and problem solving skills among nursing students. Dokuz Eylül Üniversitesi Hemşirelik Yüksekokulu Elektronik Dergisi, 2(3), 88-94.

10. Can, H., Öner, Ö.İ. \& Çelebi, E. (2009). Investigation of the effects of education on problem solving skills of university students. Firat Sağlık Hizmetleri Dergisi, 4(10), 35-58.

11. Cantürk-Günhan, B., \& Başer, N. (2009). The effect of problem based learning on students' critical thinking skills. Türk Eğitim Bilimleri Dergisi, 7(2), 451-482.

12. Choi, E., Lindquist, R., \& Song, Y. (2014). Effects of problem-based learning vs. traditional lecture on Korean nursing students' critical thinking, problem-solving, and self-directed learning. Nurse Education Today, 34(1), 52-56.

13. Dil, S. (2001). The levels of critical thinking of Hacettepe University school of nursing students. Master Thesis. Hacettepe Üniversitesi Sağlık Bilimleri Enstitüsü. Ankara.

14. Dutoğlu, G., \& Tuncel, M. (2008). The relationship between candidate teachers' critical thinking tendecies and their emotional intelligence levels . Abant İzzet Baysal Üniversitesi Ĕgitim Fakültesi Dergisi, 8(1), 11-32.

15. Elliott, B., Oty, K., McArthur, J., \& Clark, B. (2001). The effect of an interdisciplinary algebra/science course on students' problem solving skills, critical thinking skills and attitudes towards mathematics. International Journal of Mathematical Education in Science and Technology, 32(6), 811-816.

16. Görücü, E. (2014). Investigation of relationship between the reading habits and critical thinking skills of sixth, seventh and eighth grade students. Master Thesis. Yeditepe Üniversitesi, İstanbul.

17. Gürleyük, G.C. (2008). The analysis of critical thinking disposition, problem solving abilities and academic achievement levels of primary school teacher candidates with respect to some variables. Master Thesis. Zonguldak Karaelmas Üniversitesi, Zonguldak. 
18. Güven, A. \& Akyüz, M. Y. (2001). Pre-service teachers' views on communication and problem solving skills. Ege Eğitim Dergisi, l, 1322.

19. Karasar, N.(2008). Scientific research methods Ankara: Nobel Yayın Dağıtım.

20. Kayan, F., \& Çakıroğlu, E. (2008). Preservice elementary mathematics teachers' mathematical problem solving beliefs . Hacettepe Üniversitesi Ĕ̈itim Fakültesi Dergisi, 35, 218-226.

21. Kilıç, D., \& Samanc1, O. (2005). The usage of problem solving method in social knowledge lesson given in primary schools . Kazım Karabekir Eğitim Fakültesi Dergisi, 11, 100-112.

22. Koray, Ö., \& Azar, A. (2008). An analysis of high school students' problem solving and logical thinking abilities in terms of gender and preferred field. Kastamonu Ĕgitim Dergisi, 16(1), 125-136.

23. Koray, Ö., Köksal, M. S., Özdemir, M., \& Presley, A. İ. (2007). Effect of creative and critical thinking based science laboratory applications on academic achievement and scientific process skills . Ilkögretim Online, 6(3), 377-389.

24. Korkut, F. (2002). Problem solving skills of high school students. Hacettepe Üniversitesi Eğitim Fakültesi Dergisi, 22, 177-184.

25. Kösece Loğoğlu, P. (2016). The effect of mathematics instruction with activities based on Polya's problem solving method on fourth grade primary school students' success of the mathematical problem solving. Master Thesis. Mersin Üniversitesi, Mersin.

26. Neilsen. M.E.(1984). Evaluation of a rural gifted program: Assesment of attitudes, self-concept and critical thinking skills of high-abilty students in grade 3 thtough 12. Unpublished PhD Dissertation, Purdue University.

27. Nosich, G.M. (2001/2015). Learning to think things through; a guide to critical thinking across the curriculum, (Çev. Birsel AYBEK). Ankara: An1 yayınc1l1k.

28. Olkun, S., \& Toluk, Z. (2004). Activity based mathematics teaching in primary education. Ankara: Anı Yayıncılık.

29. Özdemir, S. M. (2005). Assessing university students' critical thinking skills for some variables. Türk Ĕ̈itim Bilimleri Dergisi, 3(3), 297-316.

30. Özkütük, N., Silkü, H.A., Orgun, F., \& Yalçınkaya, M., (2003). Problem solving skills of prospective teachers. Ege Eğitim Dergisi, 2, 1-9.

31. Paul, R., \& Elder, L. (2013). Critical thinking. (Çev. E. Aslan ve G. Sart). Nobel Yayıncılik, Ankara. 
32. Peter, E. E. (2012). Critical thinking: Essence for teaching mathematics and mathematics problem solving skills. African Journal of Mathematics and Computer Science Research, 5(3), 39-43.

33. Seferoğlu, S. S., \& Akbıyık, C. (2006). Teaching critical thinking. Hacettepe Üniversitesi Eğitim Fakültesi Dergisi, 30, 193-200.

34. Şen, Ü. (2009). An evaluation about Turkish teacher candidates' critical thinking attitude's in terms of difference variable. Zeitschrift Für Die Welt Der Türken/Journal of World of Turks, 1(2), 69-89.

35. Son, Y. J., \& Song, Y. A. (2012). Effects of simulation and problembased learning courses on student critical thinking, problem solving abilities and learning. The Journal of Korean Academic Society of Nursing Education, 18(1), 43-52.

36. Tanju, E. H. (2010). Book reading habit of children: A general Review. Sosyal Politika Çalışmaları Dergisi, 21(21), 30-39.

37. Thompson, S. D., Martin, L., Richards, L., \& Branson, D. (2003). Assessing critical thinking and problem solving using a web-based curriculum for students. The Internet and Higher Education, 6(2), 185-191.

38. Tümkaya, S., Aybek. B. \& Aldağ H. (2009). Investigating of critical thinking tendencies and problem solving skills of university students. Eurasian Journal of Educational Research, 36, 57-74.

39. Walsh, C.M., \&Hardy, R.C. (1999). "Dispositional differences in critical thinking related to genderand academic major. Journal of Nursing Education, 38(4), 149-155. 